\title{
MODELING THE BEHAVIOR OF BANKS IN INSTABILITY CONDITIONS
}

\author{
IVAN BURTNYAK, ANNA MALYTSKA
}

\begin{abstract}
The analysis of models of activity of banking structures in the conditions of perfect and imperfect competition is carried out. Production functions for financial companies are considered. Models of the bank's work as an institution of delegated monitoring are described. Models of dynamics of financial resources are analyzed, allow to describe processes of evolution of own capital of bank depending on dynamics of the involved resources and the policy of accumulation realized by it. The considered models and methods are based on the definition of a bank (a financial company) as some abstract object, which is characterized by input and output parameters, as well as the function that connects them. This approach to some extent allows adapting traditional models of research of industrial enterprises and organizations to the analysis of the activities of banking structures. Therefore, one of the main tasks is to optimize internal functioning. Under such conditions, it is especially important to consider the bank as a holistic complex dynamic system operating in an unstable transition economy and the use of economic and mathematical methods and models to study the processes taking place in the bank, assess its effectiveness, identify areas and ways to improve management banking activities. Based on the analysis of the main economic and mathematical models of behavior of financial companies in a monopolistic market, we can conclude that each model characterizes a certain aspect of financial market development by the situation. Production functions for a bank (financial firm) are built, where the problem of classification of these factors into input and output is significant. A wide class of economic and mathematical models is considered, in which the activity of financial and banking institutions is treated as financial intermediaries. The theory of delegated monitoring is generalized, which in the general case assumes that in conditions when there is an effect of the growth of income from scale, individual lenders prefer to delegate functions of control (monitoring) of the behavior of entrepreneurs in whose projects they have invested to special intermediary firms. banks. The analysis of the development of the banking sector of Ukraine showed that a further gradual slowdown in its pace is expected due to changes in conditions in global financial markets and market saturation.
\end{abstract}

Keywords: bank, financial company, financial market, perfect competition, production function, monitoring.

JEL Classification: C65; G13. 


\section{INTRODUCTION}

The formation of a market economy in Ukraine is accompanied by the process of developing the domestic financial and credit system. The basis of the financial and credit system is the banking system, which directly covers all parts of the single economic mechanism of the state. To date, banks have become an important factor in the business and political life of society, with their activities associated with solving a wide range of problems in transition. Conditions of fierce competition place demands on the high quality of banking services.

Banks are financial institutions that enjoy public trust, recognized as highly specialized in managing money circulation between businesses, local governments, government agencies, and society. In Ukraine, they operate based on banking legislation and are subject to banking supervision.

Referring to banking legislation, these institutions provide services called banking. It should be noted that their main task is primarily to accumulate cash resources. However, this is due to the bank's activities, which are to provide loans, borrowings, and cash settlements not only in domestic but also in foreign trade. Banks are very important institutions for the general public because they provide services to the so-called mass client.

For centuries, society, wanting to develop, borrows money for various purposes, from simple purchases to large investments. At some point in life, everyone has to use even the simplest banking service, such as opening an account. Even in this case, everyone is trying to choose the most profitable financial institution. This choice is often aided by advertisements that offer new solutions and the security of trusted funds. The bank, like any company, is focused on the profits it receives by providing services to institutional and retail customers. This leads to the efficiency of the results of services offered by the bank and the sale of advertised banking products. The client is free to choose the bank. Nowadays, along with the growing financial needs of clients, there is growing competition in the financial services market and quantitative and qualitative changes in banking, which necessitate effective efficiency management. Such a study is important because it provides information about the efficiency of banking and affects the main result - customer satisfaction, which can be reflected in the number of customers, for example, in the form of open accounts, loans, or deposits.

Economic and mathematical modeling in the field of effective management of banking is a process that is difficult to scientifically formalize. Repeated attempts to identify general principles for creating mathematical models, led either to the declaration of aggregate recommendations of a fairly general nature, which are difficult to use in practice, or, conversely, to the results that can be applied only to a fairly narrow range of specific tasks.

In terms of monetary relations, the level of development of the banking sector largely determines the real capabilities of the Ukrainian economy. At the same time, the banking system, as one of the sectors of the economy, is quite sensitive to the impact of economic cycles and financial crises. Therefore, society is primarily interested in the stable development of banks, in particular in their solvency, liquidity, as well as compliance with the acceptable degree of risk for various activities.

\section{THEORETICAL BACKGROUND}

The issue of studying the activities of banks in conditions of uncertainty is extremely complex. Often, the efficiency of the bank's operation is first singled out - this is the ratio of effects to invested resources; it can also be defined as a measure of the rationality of action [1]. The authors in [2] interpret efficiency as maximizing production, which arises as a result of proper allocation of resources with given constraints on supply (ie costs incurred by producers) and demand (ie consumer preferences). Based on [6], the concept is based on the principle of rational management, formulated in two versions: efficiency (maximizing the effect) and economy (minimizing effort). In [7] formulate efficiency as a clear activity, effectiveness, efficiency, efficiency, effectiveness, potential, and profitability. According to [8], the definition of effectiveness is extremely complex, and it is always worth referring to internal and external evaluation criteria, which depend on the context and change over time. 
Effective management of banking concerns the operational efficiency of the bank can be considered in many aspects [9].

One of the most important works on efficiency was the work [10], which proposed its evaluation using two components: technical efficiency (associated with the ability of a person to minimize costs for a given set of effects, ie cost orientation) and distribution efficiency (related with the ability of the unit to use the optimal structure of input resources, taking into account prices and used production technology - an option to minimize costs). According to [11], in the analysis of technical efficiency, the performance of the object means the relationship between real effects and real resources.

Commonly used methods of measuring efficiency are based on three approaches: index, parametric and nonparametric [12]. Regarding banks, among the classic efficiency indicators are the following: profitability, profitability, the burden on the financial result, and employment efficiency [13].

\section{Research ObJective, Methodology AND DATA}

A simple model of a bank as a financial services firm involves two types of activities: attracting deposits from savers and providing loans to borrowers. Accordingly, its condition, can be described by two parameters, namely: the volume of deposits $\mathrm{D}$ and loans $\mathrm{L}$.

The equilibrium model of the monetary base and deposits attracted by banks has the form

$$
\mathrm{W}=\sum_{\mathrm{j}=1}^{n} W_{j}=\sum_{j=1}^{n} \alpha D_{j}=\alpha D .
$$

$\alpha$ - mandatory reservation rate, $W_{j}$ - mandatory insurance reserves, which each bank transfers to special accounts of the NBU.

In addition, the model of the bank's behavior in conditions of perfect competition assumes the value of interest rates on loans $r_{L}$ and deposits $r_{D}$, the bank has no direct influence. Also, the external parameter for it is the rate of return on capital, which is present in the interbank market $r$ :

$$
\pi=r_{L} L+r M-r_{D} D-C(D, L)
$$

$r_{L} L$ - the profit that loans bring in volume $L ; r M$ - income (expenses) that the bank has on the interbank market depending on its sign; $r_{D} D$ - payments on deposits; $C(D, L)$ - the bank's costs for managing deposits in the amount of $\mathrm{D}$ and loans in the amount of $\mathrm{L}$, given by its cost function. Then the profit function can be written as a function of deposits and loans, namely,

$$
\pi(D, L)=\left(r_{L}-r\right) L+\left(r(1-\alpha)-r_{D} D\right)-C(D, L) .
$$

\section{RESULTS AND DISCUSSION}

Let The situation of perfect competition is uncharacteristic of the banking industry, which is characterized by high entry barriers. Among the most famous models of behavior of the monopolist bank can be attributed to the Monti-Klein model, see [14], within which the bank operates, according to the classical microeconomic theory of monopoly.

The model of the bank's behavior in a competitive environment can be considered as a partial case of the Monti-Klein model, if the following conditions are met $\varepsilon_{D}\left(r_{D}^{*}\right) \rightarrow \infty$ i $\varepsilon_{L}\left(r_{L}^{*}\right) \rightarrow \infty$.

Given these conditions we obtain that

$$
\frac{r_{D}^{*}(1-\alpha)-C_{D}^{\prime}-r_{D}^{*}}{r_{D}^{*}}=\frac{1}{\varepsilon_{D}\left(r_{D}^{*}\right)} \rightarrow 0, \frac{r_{L}^{*}-\left(r-C_{L}^{\prime}\right)}{r_{L}^{*}}=\frac{1}{\varepsilon_{L}\left(r_{L}^{*}\right)} \rightarrow 0
$$

that is, the conditions of competitive equilibrium. 
In the considered modifications of Monti-Klein, attention was focused on the conditions of competition according to Cournot, which provide for competition in terms of output (in the case of banks - the volume of loans and deposits). However, given the significance of the results obtained as a result of the implementation of these models, they, unfortunately, do not take into account cases where competition is not in volume but in price, ie the situation of competition according to Bertrand.

One of the factors that significantly complicate the achievement of equilibrium according to Bertrand is the so-called double competition, ie when there is a simultaneous competition between banks for both deposits and loans.

If denoted by $L\left(r_{L}\right)$ - demand for loans, and through $D\left(r_{D}\right)$ supply of deposits, then, taking into account the assumptions made traditional for the case of perfect competition, the balance according to Walras will be determined by the condition $r_{L}=r_{D}=\hat{r}$, there $\hat{r}$ the only solution of the equation $L(r)=D(r)$.

This type of equilibrium is identical to the situation when the supply and demand of monetary funds are present in some centralized market (without intermediaries). However, if we allow the existence of intermediaries and take into account that in the real economy there are no unlimited sources of funds, then there is a possibility of such a scenario in which the bank can "corner" the credit market, attracting the full amount of available deposits. Thus, competition in the deposit market can be reduced to the acquisition by one of the banks of the right to be a monopolist in the credit market. Therefore, the balance of Walras is not stable, because offering a higher rate on deposits, any of the banks will displace their competitors and become a monopolist in the credit market.

Although the concept of monopolistic competition was first presented in [15]. One of the most common models of this class is the Salop model [3], in which the differentiation between products is based on transport costs, they mean some generalized (aggregated) costs borne by the bank's client (depositor) when accessing its services. The simple formulation of the Salopa model for the banking system assumes the existence of a set of depositors (depositors) in the amount of $\mathrm{D}$, each of which has available cash reserves, which it is potentially ready to place in the bank accounts. In this case, for simplification, it is assumed that each investor has an amount whose value is equal to a conventional unit.

In the practical implementation of production and organizational models, we face the problem of building the production function of the financial and banking firm. There are two global areas of research that relate to the construction of production functions of financial and banking institutions: modeling without taking into account and taking into account intermediary activities.

The first direction originates from the works [4-5]. According to him, deposits and loans are considered as the initial parameters of its activities, and staff costs, capital investments, etc. - as input. To estimate the cost of particular banking service in [1] it is proposed to use a functional dependence of the Cobb-Douglas type:

$$
C_{i}=\text { const } Q_{i}^{\varepsilon_{i}} w_{i}^{a_{i}} r_{i}^{\left(1-a_{i}\right)}
$$

The second class of methods and approaches to the construction of the production function, in contrast to the previous one, involves accounting for the content level of the results of banks as financial intermediaries. At the conceptual level, such an approach to the construction of production functions more adequately reflects the specifics of the tasks that banks solve. It should be noted that this approach to development in [14]. It should also be noted that the results obtained in the models of both the first and second types differ very little from each other.

When constructing a production function for a bank (financial firm), the problem of classifying these factors into input and output is significant. The importance of this question, first of all, is explained by the fact that the attribution to the outputs of those factors that are not such, leads to the inevitable distortion of the true goals of the modeled object. To investigate this problem, the approach to solving classification problems, which is proposed in [15], is interesting. It introduces the term costs of using financial resources, which means net costs.

When considering various modifications of the Monti-Klein model, both direct and inverse functions were used, which relate the volumes of deposits and the value of the corresponding interest rate. $r_{D}$. 
In addition, there is a wide class of economic and mathematical models in which the activities of financial and banking institutions are treated as financial intermediaries that can be structured in the following areas.

The first includes models that treat banks as pools of depositors. The second direction is based on the concept of banks as joint owners of information. I bond $t$ is especially relevant in terms of information asymmetry. Indeed, if only individual borrowers have access to information about the characteristics of the investment project, the competitive equilibrium may be ineffective.

Finally, the third direction is related to the so-called theory of delegated monitoring. In general, it suggests that in an environment where the effect of income growth is observed, individual lenders prefer to delegate the functions of control (monitoring) of the behavior of entrepreneurs in whose projects they have invested, to special intermediary firms, ie banks.

A model illustrating the mechanism of operation of depository pools was proposed in [13]. It considers some abstract three-period economy, in which there is one conditional (generalized) resource and a finite set of agents (economic entities). We believe that at the time each of the agents owns one unit of resource. It use it either at a time (so-called early consumption) or at a time (late consumption). Under this model, a financial market opens up at the moment, in which agents can exchange the resource they have for a risk-free bond. Accordingly, at the time of the bond, you can get some resources. There is a financial market in which intermediaries operate, namely, there are institutions that can at the time accept deposits from agents.

It is believed that any market agent who has some information and wants to make money from it, faces two fundamental problems. First, if he tries to sell this information, the buyer cannot be sure of its authenticity. Second, the revenue from the sale of information may be insignificant compared to the cost of obtaining it. In a situation where price information is open, revenue may be zero. This phenomenon is called the Grossman-Stieglitz paradox [11]. In [8] we studied this problem and formulated methods for its solution in the conditions of existence of financial intermediaries.

In [1] drew attention to some features of banks' activities to transform assets, which are interpreted as financing risky projects with risk-free deposits. In an unfavorable choice, when individual agents have private information about risky projects, risk-free deposits can be used by some uninformed agents. At the same time, the proposed model showed that in the relevant economic system, the participation of financial intermediaries is optional and risk-free bonds issued directly by firms can be replaced by deposits.

The work [9] reveals interesting theoretical models that describe the work of the bank as an institution of delegated monitoring. One of them is based on the following preconditions. In some economic systems, there are identical firms that need funds to finance their projects. Firms' investment needs are considered normalized, ie each firm needs a unit of some investment. The income of firms is distributed equally and independently. Each firm, as a result of its project, system, receives some income, which is considered as the implementation of a random variable $\tilde{y}$. Its true meaning is unknown to the investor, which creates for him the problem of possible moral damage in case of dishonest behavior of the borrower. We believe that this problem can be solved in two basic ways. First, by monitoring measures (control of the borrower's behavior), which requires additional costs in the amount $\mathrm{K}$ of units. Secondly, by concluding debt contracts with penalties (fiscal) in the amount $\mathrm{C}$. It is believed that $K<C$. This condition means that if the firm has a single investor, the monitoring technology will be more effective. Each investor owns funds in the amount $\frac{1}{m}$. Thus, to finance one project you need to attract $m$ investors. In this economic system, there are at least, $m n$ investors, which provides the opportunity to finance all projects. The total cost of control will be equal $\mathrm{mnK}$.

If there is a financial intermediary (bank) in the system, the monitoring functions can be performed by it. The bank may at its discretion choose the forms in which control is exercised: each firm is controlled (total costs are equal to $n K$ ); a debt contract has been concluded with each firm (the total costs are equal to $n C$ ). The Bank acts as a delegated monitoring institution that monitors borrowers from the standpoint of creditors' interests. On the part of the bank, creditors (investors) are offered debt 
(more precisely, deposit) contracts. Under such contracts, each investor in exchange for a deposit of the number $\frac{1}{m}$ the payment of the number is guaranteed $\frac{R_{d}}{m}$. The cash flow received by the bank as a financial intermediary may be represented by a random variable

$$
\tilde{z}=\sum_{i=1}^{n} \tilde{y}_{i}-n K,
$$

$\sum_{i=1}^{n} \tilde{y}_{i}$ - the number of payments collected by the bank from borrowers, $n K$ - monitoring costs, we can conclude that the bank is liquidated if the cash flow $\tilde{z}<n R_{d}$.

It can also be argued that delegated monitoring of the bank will be more effective than direct control by the investor if and only if $n K+C_{n}<n m K$. The final result obtained based on this model can be formulated as follows:

If the control is effective $(K<C)$, opportunities for investors are limited $(m>1)$, the investment process itself brings income $(E(\tilde{y})>K+R)$ and the value of $\mathrm{n}$ is large enough (provides diversification of investments), the situation in which there are financial intermediaries will be more effective than the situation based on the use of direct control of the investor over the borrower (direct lending).

In particular, we should pay attention to the dynamic models that provide for the possibility of changing the forms of project financing at different stages of their existence. These include a two-stage model of the credit market, formulated in [4]. Its key element is a reflection of the fact that in the course of its operation a successful firm can secure a "reputation" that allows it to obtain direct loans.

In [10] the model which investigates a problem of a choice between direct and bank (intermediary) financing is considered. In it, the factor that determines the benefits of using direct financing is the amount of capital owned by the firm.

In [4] the issues of the relationship between banks and borrowers in the dynamics were studied. A key element of the models formulated in them was the idea that banks seek to establish "good" relations with borrowers to gain access to sources of information about them. Also, as in the Diamond model, it is believed that successful firms in the past have a better chance of developing their success in the future. However, it is considered that banks have reliable information only about those firms for which they were creditors in the previous stages, otherwise, banks must conduct audits of firms unknown to them.

Some models consider the functioning of financial markets in conditions of limited demand for assets, which creates the problem of restrictions on participation in financial markets. It is interesting to note that one of the conclusions obtained during the analysis of such models is that with the increase in the number of participants in the financial market, its efficiency increases and the banking sector shrinks.

The next group of models is related to the study of the coexistence of financial intermediaries and securities markets. The presence of such a factor as the securities market can significantly affect the level of awareness of economic entities and change in one way or another the situation with information asymmetry.

Many authors, in [12-15], studied the problem of ownership of information. Its essence is that borrowing firms may suffer losses if some private information about their activities becomes available to competitors. In this context, it can be concluded that the bilateral relationship between the bank and the borrower may be more effective than multilateral lending.

\section{CONCLUSIONS}

The profitability of different types of banking financial services varies greatly from bank to bank and strongly depends on the time in which data is collected, it is the division of many financial services into "inputs" and "outputs" can have strong fluctuations, making the appropriate model of production the functions of a financial firm are a very volatile object of study. Based on the analysis of the main 
economic and mathematical models of behavior of financial companies in a monopolistic market, we can conclude that each model characterizes a certain aspect of financial market development by the situation. Production functions for a bank (financial firm) are built, where the problem of classification of these factors into input and output is significant. It is proved that there is a wide class of economic and mathematical models in which the activities of financial and banking institutions are treated as financial intermediation. Based on the generalized theory of delegated monitoring, it is proved that the effect of income growth depends on the scale, individual lenders prefer to delegate the functions of control (monitoring) of the behavior of entrepreneurs in whose projects they have invested, special intermediary firms, ie banks. The analysis of the development of the banking sector of Ukraine showed that a further gradual slowdown in its development is expected due to changes in conditions in global financial markets and market saturation. At the same time, the development of Ukraine's banking sector will gradually approach the level of its development in countries with mature economies.

\section{REFERENCES}

[1] Blahun I.S., Blahun I.I., Blahun S.I. Assessing the stability of the banking system based on fuzzy logic methods. Banks and Bank Systems, 15 (3) (2020), 171-183. doi: 10.21511/bbs.15(3).2020.15

[2] Bondarenko E., Zhuravka O., John O. Structural modeling of the impact of bank nonperforming loans on the banking sector: the Ukrainian experience. Banks and Bank Systems, 15 (2) (2020), 67-78. doi: 10.21511/bbs.15(2).2020.07

[3] Burtnyak, I.V., Malytska A.P. Modelling of derivatives pricing using methods of spectral analysis. Journal of Vasyl Stefanyk Precarpathian National University, 7 (3) (2020), 7-14. doi: 10.15330/jpnu.7.3.128-136

[4] Burtnyak I.V., Malytska A. Construction of the fundamental solution of a class of degenerate parabolic equations of high order. Carpathian Mathematical Publications, 12 (1) 2020, 79-87. doi:10.15330/cmp.12.1.79-87

[5] Burtnyak I.V., Malytska A. Taylor expansion for derivative securities pricing as a precondition for strategic market decisions. Problems and Perspectives in Management, 16 (1) 2018, 224-231. doi: 10.21511/ppm.16(1).2018.22

[6] Brych V., Yazlyuk B. Prospects for use of coaching in Ukrainian banks. Banks and Bank Systems, 13 (2) (2018), 116-129. doi: 10.21511/bbs.13(2).2018.10

[7] Dmytryshyn L., Blahun I. A model for achieving the allocative efficiency of credit resources in Ukraine's banking system. Banks and Bank Systems, 11, (3) 2016, 6-14. doi: 10.21511/bbs.11(3).2016.01

[8] Kuzmenko O.V., Koibichuk V.V. Econometric Modeling of the Influence of Relevant Indicators of Gender Policy on the Efficiency of a Banking. Cybernetics and Systems Analysis, 54, (5) (2018), 687-695.

[9] Mawardi W., Mahfudz M., Laksana, R.D., Shaferi, I. Competition and financial effects between islamic and conventional banking. WSEAS Transactions on Business and Economics, 17 (2020), 101-111. doi: 10.37394/23207.2020.17.12

[10] Partovi E., Matousek R. Bank efficiency and non-performing loans: Evidence from Turkey. Research in International Business and Finance, 48 (2019), 287-309. doi: 10.1016/j.ribaf.2018.12.011

[11] Petryk O., Kurylo O., Karmaza O., Makhinchuk V., Martyniuk O. Non-financial reporting of companies and the necessity of its confirmation by auditors in Ukraine. Problems and Perspectives in Management, 16 (2) (2018), 385-395. doi: 10.21511/ppm.16(2).2018.35

[12] Poloz S.S. Integrating financial stability into monetary policy. Business Economics, 50 (4) (2015), 200-205.

[13] Salter A.W., Tarko V. Governing the banking system: an assessment of resilience based on Elinor Ostrom's design principles. Journal of Institutional Economics, 15 (3) (2019), 505-519. doi: $10.1017 /$ S1744137418000401

[14] Shvets S. The golden rule of public finance under active monetary stance: endogenous setting for a developing economy. Investment Management and Financial Innovations, 17 (2) 2020, 216-230. doi: 10.21511/imfi.17(2).2020.17 
[15] Younsi M., Nafla A. Financial stability, monetary policy, and economic growth: Panel data evidence from developed and developing countries. Journal of the Knowledge Economy, 10 (1) (2019), 238-260. doi: 10.1007/s13132-017-0453-5

Address: Ivan Burtnyak, Anna Malytska, Vasyl Stefanyk Precarpathian National University, 57, Shevchenko Str., Ivano-Frankivsk, 76018, Ukraine.

E-mail: ivan.burtnyak@pnu.edu.ua, hanna.malytska@pnu.edu.ua.

Received: March 22, 2021; revised: May 04, 2021.

Буртняк Іван, Малицька Ганна. Моделювання поведінки банків в умовах нестабільності. Журнал Прикарпатського університету імені Василя Стефаника, 8 (3) (2021), 35-42.

Проведено аналіз моделей діяльності банківських структур в умовах досконалої і недосконалої конкуренції. Розгдянуто виробничі функції для фінансових компаній. Описано моделі роботи банку як установи делегованого моніторингу. Проаналізовано моделі динаміки фінансових ресурсів, дозволяють описати процеси еволюції власного капіталу банку залежно від динаміки залучених ресурсів і реалізованої ним політики нагромадження. Розгдянуті моделі і методи, базуються на визначенні банку (фінансової компанії) як деякого абстрактного об'єкту, що характеризується вхідними і вихідними параметрами, а також функцією, яка їх пов'язує. Такий підхід в певній мірі дає змогу адаптувати традиційні моделі дослідження виробничих підприемств і організацій, до аналізу діяльності банківських структур. Тому, одним із основних завдань є оптимізація внутрішнього функціонування. За таких умов особливо важливого значення набуває розгляд банку як цілісної скдадної динамічної системи, що працюе у нестабільній економіці перехідного типу та застосування економікоматематичних методів і моделей для дослідження процесів, що протікають у банку, оцінки ефективності його роботи, виявлення напрямків і способів вдосконалення управління банківською діяльністю. На основі зробленого аналізу основних економіко- математичних моделей поведінки фінансових компаній умовах монополістичного ринку можемо зробити висновок, що кожна модель характеризуе певну сторону розвитку фінансового ринку відповідно до ситуації. Побудовано виробничі функції для банку (фінансової фірми) де істотною є проблема класифікації даних чинників на вхідні і вихідні. Розглянуто широкий клас економіко-математичних моделей, в яких діяльність фінансово-банківських установ трактується як фінансові посередники. Узагальнено теорію делегованого моніторингу, яка в загальному випадку припускає, що в умовах, коли спостерігається ефект зростання доходів від масштабу, індивідуальні позикодавці вважають за краще делегувати функції контролю (моніторингу) за поведінкою підприємців, в проекти яких вони зробили інвестиції, спеціальним посередницьким фірмам, тобто банкам. Проведений аналіз розвитку банківського сектору України показав, очікується подальше поступове уповільнення темпів його розвитку через зміни умов на світових фінансових ринках та насичення ринку.

Кдючові слова: банк, фінансова компанія, фінансовий ринок, досконала конкуренція, виробнича функція, моніторинг. 